\title{
Access to records of crime at The National Archives
}

\author{
Nigel Taylor
}

In this article I aim to give an insight into how The National Archives is dealing with the issues concerning access to records of criminals and crime at The National Archives, covering the implications of the Freedom of Information and data protection legislation and the EU right to be forgotten ruling ${ }^{1}$.

I will first give a quick overview of the holdings of the National Archives which can be used for the study of crime. The National Archives have the records of the Assizes courts and their successor, the Crown Courts and the Central Criminal Court, The King's Bench Court/King's Bench Division, Court of Appeal, Director of Public Prosecutions (DPP), Law Officers, Home Office, Prison Commission and Treasury Solicitor. In addition the records of Lord Chancellor's Department (the forerunner of the Ministry of Justice) is rich in records on legal reform, Law Commission, records on individual royal commissions including commissions on criminal procedure 1977 to1981 (BS 12) and criminal justice, 1991 to 1993 (BS 26).

The National Archives has a separate Freedom of Information Centre that deals with enquiries about closed records. The organisation receives a large number of FOI requests a year. In 2014 there were over 3000 requests for paid searches of open documents and access to closed documents, out of a total figure for FOI requests for central government of over 46,000. The National Archives figure includes over 1200 requests where information was fully withheld. The National Archives receive closure, transfer and retention applications from government departments which then form draft schedules that are presented to the Lord Chancellor's Advisory Council for review.

Sometimes documents are redacted - blacking out of certain words or sentences. However for some records, this is not possible because of the effect it would have on the rest of the information in a file. With a case file it is especially problematic.

Whereas a policy or administrative file, may only make a passing reference to a case or named individual. This is the situation with a number of care home files at The National Archives. Redaction is an awkward and time consuming process and can cause damage to a historical document.

The National Archives has internal panels which meet frequently. Firstly there is the Reclosure Panel which deal with records previously available as transferred public records where decisions needs to be made as to whether files should be reclosed. It tends to be individual cases flagged up by readers. A high percentage of these relate to criminal case files. The National Archives does not have the resources to be totally proactive in looking for records that should be reclosed, although sometimes

\footnotetext{
${ }^{1}$ Factsheet on the "Right to be forgotten ruling" European Commission (C-131/12) http://ec.europa.eu/justice/data-protection/files/factsheets/factsheet_data_protection_en.pdf
} 
staff are alerted to problematic series. In these circumstances other records in a series will be examined. A selection of Director of Public Prosecutions Case Papers have been withdrawn in line with the reclosure policy. This covers nearly 1000 files out of a series containing about six and a half thousand files. The records do contain graphic crime and post mortem details including photographs and medical reports. In 2011 the FOI Centre began a project to review approximately 400 open archival files relating to gay sex offences. This project was a result of a risk assessment of open records many of which have been decriminalised since the offences were committed. As of November 2012, fifty per cent of the files, which even included military tribunal cases, had been reviewed with around eighty per cent having been found to contain sensitive personal information which should be reclosed. Leaving the information in the public domain is likely to be a breach of the Data Protection Act and would attract criticism from the Information Commissioner. Because of the staff time involved it was decided to wind up the project and give a blanket closure for these type of files. Most decisions made by the reclosure panel are pretty clear cut. Most of them are based on section 40 and section 38 of the Freedom of Information Act. It is taken into account whether information is already in the public domain. For example a published book on a particular crime and how many readers have already ordered and looked at a particular file. Checks will also be made in the death indexes to see if a subject is still alive. Often the most difficult decisions are where descendants of a person mentioned in a file are claiming that the file being open is causing them mental distress.

There is also the Takedown Panel which concerns material on the National Archives website and archived websites. As a general rule information published on a website will be considered in the public domain and will only be removed in exceptional circumstances. Reasons to take down include being considered subject to an exception under the Freedom of Information Act, personal information about someone still alive where online access would be unlawful or unfair under the Data Protection Act 1998 or breach their family's right to a private life under the Human Rights Act 1998, breach of copyright and where the material was released in error. Obviously there is a cross-over with the work of the reclosure panel.

Government departments undertake Privacy Impact Assessments to investigate the privacy impact on living individuals. The National Archives is undertaking a Privacy Impact Assessment of the Assizes Crown Minute Books which include the charges verdict and sentence for each case. Unusually in this case, it been used on records that have been in the public domain for many years. The Ministry of Justice has a so called Privacy Impact Assessment screening template which guides their staff. 
The Ministry of Justice gives guidance on sensitivity reading of criminal court trial files for their own staff based on a joint comprehensive review between Ministry of Justice (then known as the Department of Constitutional Affairs). ${ }^{2}$ The document mentions that although justice is public in the UK with public access to court rooms in most instances, it does not mean the contents are necessarily public. It also mentions Privileged Access Agreements whereby certain persons can gain access to closed documents under strict conditions, e.g. not copying of documents and not to make public the names on files. It acknowledges that many researchers are studying crime trends or techniques of investigation and do not need personal data. The department is also sympathetic to close relatives who wish to see closed material. It mentions that feed-back from relatives suggests they often get closure on troubled aspects of their lives. This system allows them to forewarn researchers or relatives about the distressing nature of some material.

EU right to be forgotten ruling of 2014 is especially significant for the National Archives as its Discovery Catalogue is searchable via google and other search engines. Requests have been made to remove material. It is acknowledged that a distinction has to be made between the ease of someone finding information by searching the internet and someone who visits our archive to search through documents. Many DPP file descriptions are quite detailed including the name of a victim and place of crime although it agreed between representatives of the National Archives and Director of Public Prosecutions to limit the information in the future, although the motive here was more because of limited resources at the DPP.

There is ongoing discussions between The National Archives and the Ministry of Justice concerning closure periods for court records. There is certainly an inconsistency with petty sessions/magistrate court records. Some local archives have been advised by their local Magistrates court to change the closure period to up to 100 years, presumably with guidance centrally from the Ministry of Justice including for records that were previously open after thirty years. As these type of records include many custody and child maintenance cases there is some justification for the extended closure period. The National Archives and the Ministry of Justice are trying to reach an agreement on a uniform closure period for newly accessioned court records, apart from the type of case files that normally have extended closure periods

The Ministry of Justice argument is that all court records contain personal information. So the new twenty rule replacing the old thirty year rule will not impact in the same way that it will do for other government departments. There is also the question of how files are sampled. There are guidelines in existence which help to produce consistency in the sample process of what is kept - the minority and what is destroyed - the majority. But in these times of budget cuts, departments will look to see how they can save money in the selection and transfer process. For example

\footnotetext{
${ }^{2}$ Privacy Impact Assessments guidance. Data Access \& Compliance Unit July 2014 (Ministry of Justice)
} 
possibly only having a commitment to keep every multiple murder case file rather than files for every murder. Although there is a commitment to keep every indictment produced, it may be that fewer case files are kept. This could to be a challenge for future legal historians and may leave more disappointed people who are looking to see if a particular file has been retained. 